\title{
Türkiye Yayıncılık Tarihinin Farklı Bir Uğrağı: Amatör Radyoculuk
}

\author{
Yrd. Doç. Dr. Süleyman ILASLAN
}

fırat üniversitesi iletişim fakültesi radyo, televizyon ve sinema bölümü suleyman.ilaslan@gmail.com

\begin{abstract}
A Different Moment of Broadcasting History of Turkey: Amateur Radio Broadcasting

We meet the different developments in the history of broadcasting which importance should not be neglected when studying on the development of state and commercial broadcasting. This historical process and developments which disappeared in the dominant narratives of media history are essential resources to provide a better opportunity to assess both the historical as well as contemporary media environment and broadcasting policy. In this context, there are many issues waiting to be explored in the history of Turkey broadcasting. In this study, a little known aspect of the history of broadcasting in Turkey, history of amateur radio broadcasters of Turkey, will investigate. The starting point of the study is the history of broadcasting in Turkey has a more vivid past and this past has a diversity which move us beyond the boundaries of state/commercial broadcasting. In this context, the rise of demands and initiatives for amateur radio broadcasting and amateur radio activities which carried out in manner devoid of any legal basis in Turkey between 1945-1980 are investigated.
\end{abstract} control

keywords: radio, amateur radio broadcasting, state monopoly, 


\section{Résumé}

\section{Une escale différente de l'histoire de radiodiffusion en Turquie: Les Radioamateurs}

Quand les thèmes principaux qui ont le sujet de radiodiffusion commerciale et étatique sur I'histoire de radiodiffusion sont suivis, nous sommes confrontés avec l'importance de l'existence des développements qui ne devra pas être négligée hors de ce processus historique. Ce processus et les développements qui ont disparu dans les récits dominants de l'histoire des médias historiques sont des ressources essentielles pour fournir une meilleure occasion d'évaluer à la fois l'environnement médiatique historique et contemporaine et la politique de radiodiffusion. Dans ce contexte, il y a plusieurs sujets qui attendent être analysés dans I'histoire de radiodiffusion de Turquie et donc l'histoire de radio est I'un des exemples principaux parmi eux. Dans cette étude, un aspect peu connu de I'histoire de la radiodiffusion en Turquie, sera analysé. Le point de départ principal de l'étude est l'idée de l'histoire de radiodiffusion de Turquie est plus vivant et ancien que ce qu'il est pensé et cette histoire nous apportera a une diversité qui sera au-delà des frontières de l'histoire de radiodiffusion en Turquie. Dans ce contexte, il s'agit de suivre l'augmentation de demande et d'initiative pour la radiodiffusion et les activités des radioamateurs qui sont effectué sans aucun support légal en Turquie entre les années 1945 et 1980.

mots-clés: radio, radioamateurs, monopole du gouvernement, contrôle

\section{Öz}

Yayıncılık tarihi üzerine çalışmaların devlet ve ticari yayıncılığı konu alan temel izlekleri takip edildiğinde karşımıza bu tarihsel sürecin dışında ve önemi ihmal edilmemesi gereken gelişmelerin varlığı çıkmaktadır. Hâkim medya tarihi anlatıları içinde gözlerden kaybolan bu tarihsel süreçler ve gelişmeler hem tarihi hem de günümüz medya ortamını ve yayıncılık politikalarını daha iyi değerlendirme imkânı sunacak temel kaynakları bünyesinde barındırmaktadırlar. Bu bağlamda, Türkiye yayıncılık tarihinde de araştııılmayı bekleyen birçok konu bulunmakta, radyo tarihi de bunun önemli bir örneği olarak ön plana çıkmaktadır. Bu çalışmada Türkiye yayıncılık tarihinin az bilinen bir yönü, Türkiye radyo amatörleri tarihi araştırılacaktır. Çalışmanın temel çıkış noktası Türkiye'de yayıncılık tarihinin sanılı̆̆ından daha canlı bir geçmişe ve bu geçmişin bizi devlet/ticari yayıncılık sınırlarının ötesine taşıyacak bir çeşitliliğe sahip olduğu düşüncesidir. Bu kapsamda 1945-1980 arası dönemde Türkiye'de radyo amatörlügü talep ve girişimlerinin yükselişi ve yasal dayanaktan yoksun bir biçimde sürdürülen amatör radyoculuk faaliyetlerinin izi sürülmektedir.

anahtar kelimeler: radyo, amatör radyoculuk, devlet tekeli, kontrol 


\section{Giriş}

Michele Hilmes, hiçbir aracın tarihçiler ve medya araştırmacılarınca 1920'lerden televizyonun yayıldığı 1950'lere kadar geçen sürede en önemli iletişim aracı konumuna yükselen radyo kadar unutulmadığına değinerek, radyonun "karanlık ve solan hafıza" olduğunu belirtmektedir. Ona göre, "radyonun enformasyonun iletimi ve kontrolü için bizim temel toplumsal yapılarımızdan biri olarak kurumsallaşması" radyoyu toplumsal tarihle ilgili her türlü incelemeyle bağlantılı kılmaktadır. Dolayısıyla radyo inmal edilmemesi gereken bir çalışma alanı olarak karşımızda durmaktadır (1997, s. xiv, xvi). Radyo tarihi gerek yayıncılığın gelişimi gerekse iletişim araçlarının toplumsal hayattaki yeri ve rolü açısından en canlı araştırma alanlarından birini sunmaktadır. Robert McChesney'in tabiriyle bu alan yayıncılığın birçok "gizli tarihi"ni içinde barındırmaktadır (1993, s. 254). Bu çalışma kapsamında olduğu gibi, amatör radyoculuğun izini sürmek de bizi bu "gizli tarihlere" ulaştırmada kritik bir önem taşımaktadır.

1900'lerin ilk çeyreği bu açıdan önemli veriler sunmaktadır. Bu dönemde karşımıza radyo yayıncılığının gelişimine yaptıkları önemli katkının yanı sıra alanın hâkim aktörleri olarak radyo amatörleri çıkmaktadır. Ancak radyo kısa sürede gerek devletler gerekse ticari tekeller tarafından amatörlere bırakılamayacak kadar önemsenen bir araç konumuna yükselmiştir. Hâkim yayınclık sistemlerinin şekillenmesi ve amatörlerin alandan dışlanması bu andan itibaren -bu dönüşümde 1920 'li yıllar büyük önem taşır- gerçekleşmiştir. Böylece devletlerin ve şirket çıkarlarının alana nüfuz ettiği ve yayıncılığı tekelleri altına alarak şekillendirdikleri bir süreç yaşanmıştır. Bu durum birçok ülkede amatör radyoculuğun ortaya çıkışı ve gelişimi üzerinde temel bir rol oynamış, bu faaliyet bazı ülkelerde -özellikle Avrupa ülkeleri- daha en başından yasaklanmış, amatörler yalnızca dinleyici olarak konumlandırımışlardır.

Bu çerçevede radyo yayıncılığı tarihine baktığımızda radyo amatörlerinin inmal edilmemesi gereken bir araştırma konusu olarak belirdikleri görülmektedir. Bu çalışmada, amatör radyoculuk olarak adlandırılan ve iletişim tarihinde yer etmiş bu uğraşın Türkiye'de var olup olmadığı araştırılacaktır. Çalışma, Türkiye yayıncılık tarihi üzerine araştırmaların azlığı nedeniyle ve bu konunun daha fazla ve derinlemesine incelenmesi gereğinden doğmuştur. Çalışmanın temel çıkış noktası, Türkiye'de de yayıncılık tarihinin sanıldığından daha canlı bir geçmişe sahip olduğu ve bu geçmişin bizi devlet/ticari yayıncılık sınırlarının ötesine taşıyacak verimlilikte olduğu düşüncesidir. Türkiye'de radyo ve televizyon yayıncılı̆̆ı 1990 öncesi dönemde devlet tekelinde şekillenmiş olsa da devlet tekeli dışında yayıncılık alanında faaliyet gösteren çeşitli kuruluşların ve bireylerin varlığının Türkiye yayıncılık tarihinde önemli bir yer tuttuğu düşünülmektedir. Bu doğrultuda öncelikle dünyada yayıncılığın gelişimi incelenecek, bu konuda öncü olan $A B D^{\prime}$ de ve Avrupa ülkelerinde amatör radyoculuğun bu gelişimin ilk dönemlerinde oynadığı temel rolün izi sürülecek ve ardından da yayıncılığın devletler ve ticari tekellerce kontrol altına alınış sürecine değinilecektir. Bu 
süreçte amatör radyoculuğun marjinal bir konuma itilişi ele alınacaktır. Ardından Türkiye'de radyonun kuruluşu ve gelişimi bağlamında amatör radyoculuğun ortaya çıkışı ve gelişimi incelenecektir.

Bu kapsamda, Türkiye'de 1945 sonrası dönemde amatör radyoculuğun varlığı yadsınamayacak bir gelişim gösterdiği ileri sürülmekte ve bu gelişimin izi gazetesinin elektronik arşivi, Devlet Planlama Teşkilatı (DPT), PTT Genel Müdürlüğü ve Türkiye Radyo ve Televizyon Kurumu (TRT) gibi kurumların resmi belgeleri ve Türkiye Radyo Amatörleri Cemiyetinin 1964 yılından itibaren yayımlamaya başladığı üzerinden tarihsel olarak sürülmektedir. Amatör radyoculuk üzerine gerçekleştirilen bu çalışmanın Türkiye'de devlet tekeli döneminin ve kavramının radyo ve televizyon yayıncılığı açısından daha iyi kavranmasına ve bu tekelin ve kontrolün daha eleştirel bir biçimde ele alınmasına katkı sunacağı düşünülmektedir. Bu durum, ayrıca, Türkiye'de de radyonun teknik ve siyasi boyutların ötesinde toplumsal hayatta kendisine farklı biçimlerde yer bulan bir araç olduğunu göstermesi açısından önemlidir. Çalışma temel olarak iki döneme odaklanmaktadır: Türkiye'de yaşanan toplumsal, siyasi ve ekonomik yeniden yapılanma süreçlerinde, demokratikleşme umutlarının yükselişine paralel olarak amatör radyoculuğun serbest bırakılmasına dair taleplerin yoğun bir biçimde dile getirildiği ve ilk amatör radyoculuk derneklerinin kurulduğu 19451955 arası dönem ve 1960-1970 arası dönemdir. Bu dönemlerde sırasıyla kurulan Türkiye Radyo Amatörleri Derneği (TRAD) ve Türkiye Radyo Amatörleri Cemiyeti (TRAC) etrafında yaşanan gelişmeler ve tartışmalar, bu derneklerin faaliyetleri ve girişimleri çalışmanın temel çerçevesini oluşturmaktadır.

\section{Telsizle Haberleşmeden Radyo Yayıncılığına Amatör Radyocular ve Amatör Radyoculuk}

Amatör radyoculuk iletişim tarihinde telsiz telgrafın gelişiminden radyo yayıncılığının ortaya çıkışı ve şekillenişine kadar geniş bir süreçte temel bir rol oynamış, uzun radyo tarihinin hemen her aşamasında yoğun biçimde karşılaşılan bir faaliyet olmuştur. Bu bağlamda amatör radyoculuğun ortaya çıkışı ve gelişimi telsiz telgrafın keşfiyle birlikte başlatılmakta, radyo yayıncılığının gelişimiyle bağlantıı olarak ele alınmaktadır. 1900'lerin başlarından itibaren amatör telsizciler kendi yaptıkları telsizler aracılığıyla birbirleriyle haberleşmeye ve bir araya gelebilecekleri kulüpler oluşturmaya başlamışlardır. Aynı dönemde ordunun ve şirketlerin bu yeni araca yoğun ilgi göstermesi telsiz telgrafın gelişimini ve yaygınlaşmasını hızlandırmıştır. Bununla birlikte, amatör telsizciliğin daha ileri bir boyuta, radyo yayıncılığının temellerini oluşturacak niteliğe kavuşması 1900 'lerin ilk on yılında Lee De Forest'ın hertz dalgalarıyla seslerin ve müziğin aktarılabileceğini ispatlamasıyla gerçekleşmiştir. Bu gelişmeler sayesinde daha önce yalnızca iki nokta arasında iletişim kurmak için kullanılabileceği düşünülen telsiz telgrafın aslında aynı anda çok daha fazla kişiye erişim imkânı sunan bir nitelikte olduğu görülmüş, amatörlerce ve ticari kuruluşlarca ilk radyo istasyonu örnekleri hayata geçirilmiş ve böylece amatör radyoculuk hızla yaygınlaşan bir 
faaliyet alanına dönüşmüştür (Briggs ve Burke, 2011, s. 181-185; Douglas, 2010, s. 315-316; Hilmes, 1997, s. 41, 43-44; Walker, 2001, s. 13, 19, 24-25).

Radyo yayıncılığı şekillenmeden önce telsizin giderek yoğunlaşan kullanımı ve amatör radyoculuğun yükselişi özellikle ABD'de karşımıza çıkmaktadır. Daha 1915 yılına gelmeden amatör radyocular adlarından söz ettirecek bir sayıya ulaşmışlardır. ${ }^{1}$ Radyo amatörlerinin giderek artan sayısı ve haberleşmede artan karmaşa radyo frekanslarının kullanımı konusunda tartışmaları ve askeri ve ticari çevrelerin frekansların amatörlerce serbestçe kullanımından duydukları rahatsızlığı dile getirmeye başlamalarını beraberinde getirmiştir. Alandaki ilk düzenleme de bu bağlamda ortaya çıkmıştır. 1912'de çıkarılan Radyo Yasası radyo işletme yetkisini lisansa bağlamış, frekansların kullanımını düzenlemiş ve amatör radyocuların faaliyet alanını sınırlandırmıştır (Douglas, 2010, s. 315-318; Walker, 2001, s. 16, 19-22, 25). Bu andan itibaren atılan adımlar Birinci Dünya Savaşı sonrası dönemde yaşanacak değişimin ve böylece alanda belirecek devlet ve tecimsel mantık hâkimiyetinin habercileri olurken, amatör radyoculuğun geleceği üzerinde de temel bir rol oynamışlardır. Bu bağlamda amatör radyocular radyo dalgalarının kamunun aktif kullanımına kapatıldığı ve "güçlü bir azınlık tarafından tekelleştirilme"ye başlandığı bir döneme tanıklık etmişlerdir (Walker, 2001, s. 13, 15).

Birinci Dünya Savaşı sonrası bu dönüşümün yaşandığı dönem olmuştur. Bu, radyo dalgalarının daha önce hiç olmadığı kadar önemsenmeye ve kontrol altına alınmaya başlandığı bir dönemdir (Hilmes, 1997, s. 48-49; Walker, 2001, s. $14,15,27)$. Hilmes, ABD'deki bu kontrol çabasının temelde amatör radyocular üzerindeki denetimsizlikten kaynaklanan kültürel kontrolü kaybetme endişesine dayandığını, bu çatışmanın devletin daha fazla müdahil olma eğilimi ve amatör radyoculuğun 1922'de denetim altına alınmasıyla sonuçlandığını aktarmaktadır. Bu bağlamda amatör radyoların "hava durumu, piyasa haberleri, müzik, konser, söz yayınları, haberler ya da benzer enformasyon ya da eğlence programları yayınlama konusunda lisanlarının olmadığı", bu tür yayın yapmak isteyenlerin bir istasyon olarak lisans alması gerektiği hükme bağlanmıştır. Böylece ilk kez "amatörler" ve "yayıncılar" olmak üzere bir ayrıma gidilmiş, amatörlerin yayıncılıkla bağları koparılmıştır (1997, s. 48-50).

Böylece, 1920'lerde ABD'de ve Avrupa'da devletin gerek doğrudan gerekse dolaylı müdahaleleri yayıncılık alanını kamu ve ticari modeller etrafında şekillendirmiştir (Briggs ve Burke, 2011, s. 168-171; Curran ve Seaton, 2003, s. 107-110; McChesney, 1993). Bu süreçte amatör radyocular ABD'de daha geri plana itilirken, zaten en başından amatör telsizciliğin bir dinleme faaliyeti olarak belirdiği Avrupa'da serbestçe faaliyette bulunma umutlarını en başından kaybetmişlerdir (Briggs ve Burke, 2011, s. 186-189; Walker, 2001, s. 173).

1 Douglas, 1910 yılında amatörlerin özel şirketlerden ve ordudan daha fazla sayıda olduğunu (2010, s. 316), Walker ise, 1914 yılına gelindiğinde amatör radyocuların sayısının on bini bulduğunu belirtmektedir (2001, s. 16). 
Bununla birlikte, Avrupa'da amatör radyocular yasal dayanaktan yoksun olarak faaliyetlerini gerçekleştirilmeye devam etmişlerdir (Stevenson, 1996). Frekanslar devletlerin ve büyük şirketlerin hâkimiyetinde ve bunlar tarafından kullanılan bir yapıya büründükçe amatör radyocuların kısa dalga üzerinden çok sınırlı bir alanda ve yayın yapmaktan ziyade ağırlıklı olarak dinleme ve karşııklı etkileşim kurma şeklinde faaliyet göstermeleri kaçınılmaz bir gelişim seyri olmuştur.

1930 'larla birlikte radyonun öneminin fark edilmesi ve bu bağlamda hızla siyasi bir araca dönüştürülmesi ise (Briggs ve Burke, 2011, s. 242-243, 244; Jeanneney, 2009, s. 62-65, 153-157, 168-171) amatör radyoculuğun bu seyrini pekiştirmiş, kısa dalga frekanslarda bile rahatça faaliyet gösterememelerine yol açan gelişmeleri beraberinde getirmiştir. Ulus devletlerin bu dönemde kısa dalga üzerinden yoğun bir radyo propagandasına ya da bir başka deyişle uluslararası yayın faaliyetine yönelmeleri bu frekansları kontrol eğilimlerini arttırmıştır (Briggs ve Burke, 2011, s. 242-244; Jeanneney, 2009, s. 172, 174-177). Bu gelişme amatör radyocular üzerinde de köklü bir etki yaratmış, devletlerin tutumları ve büyük güçte vericilerle kurdukları çok sayıda uluslararası kısa dalga radyo istasyonu karşısında faaliyet alanları giderek daralmıştır. Bu radyoların hâkimiyeti karşısında amatör radyoculukta DX'cilik olarak adlandırılan uğraş ön plana çıkmıştır. Uzaklardan yapılan yayınları dinleme faaliyeti olarak adlandırılan DX'cilik amatörler arasında giderek daha fazla yaygınlaşmıştır (Briggs ve Burke, 2011, s. 184-185). Bunun yanı sıra, aynı dönemde, yerel kısa dalga yayınlar yapan -ulusal ya da bölgesel çapta- istasyonların sayısındaki artış da amatörler arasında dinleme eğiliminin ön plana çıkmasında önemli bir rol oynamıştır (Berg, 2008, s. 10-21). Böylece 1945 sonrası kısa dalga yayıncılığın tüm dünyaya yayıldığı uzun bir dönemin başlangıcı olurken (Berg, 2008, s. 414-415; Mattelart, 2001, s. 67-68), giderek artan kısa dalga istasyon sayısı amatör radyoculuğu hem dönüştürmüş hem de biraz daha sınırlandırmıştır. Uzun tarihsel süreç radyo dalgalarının amatörlerce kullanımının önüne hemen hiçbir dönem tamamen geçil(e)mediğini ortaya koymuş olsa da, radyoya demokratik potansiyelini veren frekansların kamu tarafından aktif kullanımı ve küçük çaplı vericilerle insanların seslerini duyurabilme imkânının büyük ölçüde ortadan kaldırılışına tanıklık etmiştir. ${ }^{2}$

\section{Türkiye'de Radyo Yayıncılığının Kuruluşu ve Gelişimi: Amatörlerce Gerçekleştirilen Illk Radyo Denemeleri ve İlan Edilen Devlet Tekeli}

Radyonun dünyada ortaya çıkış ve gelişim sürecine bakıldığında Türkiye'nin radyoyla tanışmasının da 1920'ler gibi erken bir tarihte gerçekleştiği görülmektedir. Yine dünyadaki gelişmelere benzer bir biçimde radyoya duyulan ilginin daha o yıllarda ilk "radyo meraklılarını" ya da bir başka deyişle radyo amatörlerini -her ne kadar sayı ve faaliyet açısından dünyayla bir kıyaslama söz konusu edilemese de- ortaya çıkardığı söylenebilir (Bener, 1941, s. 4; Kocabaşoğlu, 2010). Uygur

2 Bu noktada demokrasinin gelişimi ile iletişim araçlarının kurumsallaşma süreci arasındaki ilişkiye liberal demokrasi ve yurttaşlık kavramları üzerinden odaklanmanın temel bir önem taşıdığı belirtilmelidir. Bu konudaki tartışmalar için bkz. Demirci, 2014; Demirci, 2015. 
Kocabaşoğlu, ilk radyoculardan Ruşen Ferit Kam'ın 1920-1922 arası bir tarihte bir Fransız gemisinden yapılan yayınları Darülfünun konferans salonunda üniversite öğrencilerine dinlettirdiğini anımsadığını aktarırken Türkiye'deki amatör çabaların varlığına ve bu faaliyetin ne kadar eski bir tarihe uzandığına dair de bir kanıt sunmaktadır. Bunun yanı sıra, yine aynı yıllarda ilk radyo yayını denemelerini gerçekleştirenlerin radyo amatörleri olduğu bilinmektedir (2010, s. 35). Ancak bu ilk tanışma anından sonra amatörlerin radyoyla olan bağı yasalarda ilan edilen devlet tekeliyle koparılmış ve radyo amatörlüğünün yalnızca dinlemeyle sınırlandırılan bir yapıda tanımlanması ve gelişmesine izin verilmiştir. Bunda, 1920'lerin başlarından itibaren telsiz telgrafın önemini kavramış olan devletin bu aracı kontrol altında tutma ve kullanma isteği temel bir rol oynamıştır. 8 Eylül 1926'da Türk Telsiz Telefon Anonim Ortaklığı ile hükümet arasında imzalanan Türkiye Cumhuriyeti Havza-i Hükümeti Dahilinde Telsiz Telefon Mürsile ve Ahize İstasyonları İşletme Ruhsatnamesi'nin 11. maddesi bu kontrolün hem yayın faaliyetleri hem de dinleyiciler üzerinde sağlanmak istendiğini açık bir biçimde ortaya koymaktadır:

Madde 11: Genel Müdürlük yayın hizmetini bütünüyle ya da kısmen tatil etmek ve bazı abonelerin radyo kullanmalarını men etmek ve fevkalade hal halinde, görülecek lüzum üzerine, istasyonlara bütünüyle el koymak hak ve yetkisine sahiptir (...) (akt. Beşiroğlu, 1977, s. 5).

Benimsenen bu tutum radyonun gücü konusunda duyulan endişelerin daha ilk yıllardan itibaren ne kadar yoğun olduğunu yansıtmaktadır. Bu yaklaşım radyo tekniğine duyulan amatör ilginin gelişmesi önünde ciddi bir engel oluşturmuş, amatör radyoculuk yalnızca yayınları dinleme çabası ile sınırlandııımıştır. Aslında bu tutum 1920'lerde amatörleri yayın bandından ve faaliyetlerinden uzaklaştırarak birer dinleyici konumuna yerleştirmek isteyen ve bunu gerçekleştiren birçok ülkeyle -özellikle Avrupa ülkeleri- benzerlik göstermektedir. Bu bağlamda Kocabaşoğlu, amatör radyoculuğun daha 1920'lerde basit bir alıcı yapma ve bu alıcılarla yayınları takip etme biçiminde anlaşıldığını ve amatör radyocular için bu yönde teknik bilgiler veren yazılar yayımlandığını aktarmaktadır. Ona göre, amatör radyoculuğa yönelik bu yaklaşım ve amatör radyoculuğun gelişmemesi radyonun Türk toplumunun bir ürünü olmaması ve radyoya gereksinim duyacak toplumsal kurumların gelişmemiş olması ile yakından bağlantııdır. Bunun yanı sıra, devletin en başından itibaren alanda tekelini ilan etmesini, radyo üretimi yapacak bir sanayinin yokluğunu ve radyo parçalarının son derece pahalı olmasını amatör radyoculuğu engelleyen temel unsurlar olarak sıralamaktadır (2010, s. 33). Tüm bu unsurlar Türkiye'de amatör radyoculuğun gelişimi karşısında ciddi bir engel oluşturmuşlardır. Bununla birlikte 1920'lerin ilk yıllarında radyoya ilgi duyan ve amatör çabalarla ilk yayınları gerçekleştiren insanların varlığının Türkiye'de de amatör radyoculuğun ilgi duyulan ve gelişmeye müsait bir potansiyele sahip olduğunu göstermesi açısından vurgulanması gereken bir nokta olduğunu belirtmek gerekir. 
1927 yılında ilk düzenli yayınların başlamasıyla birlikte radyoya duyulan ilgi artarken, radyo meraklılarının birer radyo alıcısı yaparak yayınları dinleme çabaları da belirginleşmeye başlayan bir uğraş haline gelmiştir (Bener, 1941, s. 4). Bununla birlikte 1928 senesinde gümrük tarifelerinin yükselmesi yerli üretim yapan sanayinin olmadığı bu ortamda radyo parçalarına ulaşmayı güçleştirmiş ve amatör radyoculuğun gelişimi önüne ciddi bir engel daha çıkarmıştır (Kaçan, 1969 , s. 3).Ancak bir alıcı yaparak yayınları dinleme çabası ilgi duyulan bir faaliyet olmaya devam etmiştir (Ertuğ, 1945a, s. 3; Kocabaşoğlu, 2010, s. 33). 1930'larda radyo cihazı satıılarının gazetelere verdiği reklamlara bakıldığında radyo merakının temel olarak dünyanın farklı yerlerinden yayın yapan istasyonları dinleme çabası etrafında tanımlanmaya başlandığı net bir biçimde görülmektedir. Ancak bu ilgi ve çabaların İkinci Dünya Savaşı sonrası döneme kadar belirgin ve örgütlü bir biçimde ön plana çıkmadığını belirtmek gerekir. Bunda 1930'larda yaşanan siyasi ve ekonomik gelişmelerin, giderek katılaşan yönetim anlayışı karşısında devletin artan kontrol isteğinin ve İkinci Dünya Savaşının temel bir rolü vardır. ${ }^{3}$ Bu ortamda devletin tekeli dışında gerçekleştirilecek radyo faaliyetleri ciddi bir tehdit olarak görülmüştür. Bu durum amatör radyoculuğa dair algının değişmesini engellemiştir.

\section{Tarihli Telisiz Kanunu ve Amatör Radyoculuk}

23 Haziran 1937'de çıkarılan 3222 sayılı Telsiz Kanunu amatör radyoculuğun geleceği açısından temel önemde bir düzenleme olmuştur. Kanun, radyo tekelinin yanı sıra işletme yetkisinin de devlete ait olduğunu yasal hükme bağlamıştır. Bu düzenlemenin konumuz açısından yansıması ise zaten engellenmekte olan amatör radyoculuğun katı bir biçimde yasaklanmaya devam etmesi olmuştur. Kontrolsüz ve devlet tekeli dışındaki telsiz haberleşmesinin ve radyo yayınlarının ülke güvenliğini tehdit edeceği yönündeki düşüncelerin bu dönemde belirginlik kazandığı söylenebilir. Güney Gönenç, bu kaygının "düşmanın işine yarar" anlayışı etrafında şekillendiğine vurgu yapmaktadır (1977, s. 252).

Telsiz Kanunu'yla devlet kurumları dışında yapılacak tüm yayıncılık girişimlerinin yasaklanması kararlaştııımıştır. Yasanın 5. maddesinde: lüzumu halinde resmi kurumlara telsiz kurma izni verilebileceğine değinilirken, 6. maddesi kamu kurumlarına izin verilmesi konusunda bile ciddi kaygıların olduğunu yansıtmaktadır. Maddede, kurumlara izin verilmesi halinde kurulacak telsiz tesisatının Nafia Vekâletinin görevlendireceği memurlarca sıkı bir kontrole tabi tutulacağı vurgusu bunun açık bir göstergesidir. Ruhsat verilmediği halde verici ve alıcı kuran şahıslara ise cezai işlem uygulanacağı hükme bağlanmıştır (Resmi Gazete, 23.06.1937). Bu hükümler radyo haberleşmesinin ne kadar sıkı bir kontrole tabi tutulacağını göstermektedir. Bununla birlikte yasanın 2. maddesiyle, askeri kurumlar dışında, yalnızca eğitim kurumlarına, yine eğitim amacıyla,

3 1930'larda yaşanan siyasi ve ekonomik gelişmeler için bkz. Ahmad, 1983; Keyder, 2003; Tunçay, 1983; Zürcher, 2007 
istasyon kurma ve işletme izni verilmiştir (Resmi Gazete, 23.06.1937). Bu iznin telsiz alanında ihtiyaç duyulan teknik personeli karşılama gereksinimiyle yakından bağlantılı olduğu söylenebilir. Bu madde, İkinci Dünya Savaşı sonrasında oluşan uygun ortamın da etkisiyle, 1945 sonrası dönemde Türkiye'de devlet tekeli dışında yeni radyo istasyonları kurulmasına ve amatör radyoculuk faaliyetlerinin yükselmesine dayanak sağlayacaktır. Ancak araya giren Ikinci Dünya Savaşının yarattığı duraklama, değil amatör radyoculuk devlet radyosunun gelişimini bile durma noktasına getirmiştir.

\section{İkinci Dünya Savaşı Yılları: “Radyo Dinleme Özgürlüğü”}

İkinci Dünya Savaşı radyonun bir propaganda aracına dönüştürüldüğünü kesin bir biçimde ilan etmiştir (Briggs ve Burke, 2001, s. 243). Bu gelişmeler bağlamında, Türkiye gibi savaşın dışında kalan devletler bile radyolar aracılığıyla yürütülen propagandanın içinde kendi radyolarını yeniden düzenleyerek daha sıkı bir devlet denetimi kurma ihtiyacı hissetmişlerdir (Ertuğ, 1951, s. 56; Kocabaşoğlu, 2010). Bu doğrultuda, yalnızca dinlemeyle sınırlandırılan amatör radyoculuk karşısındaki tutumun İkinci Dünya Savaşı yıllarında da sürdürülmeye devam ettiği görülmektedir. Ancak buna karşın bu dönemde sık sık Türkiye'de radyo dinleme özgürlügünün mevcut olduğuna vurgu yapıldığı görülmektedir. 1940'larda Matbuat Umum Müdürlüğü tarafından yayımlanan dergisinde yabancı ülkelerden yapılan yayınları dinlemenin bir sakıncası olmadığına vurgu yapılması, bunun için yabancı radyoların dinlenebileceği frekans ve saat bilgilerine yer verilmesi bu bakımdan daha anlaşılır olmaktadır (bkz. Radyo 1941, c.1, s.1, ss. 14-15, 30-31; 1941, c.1, s.2, ss. 34-35; 1945, c.4, s.46, ss. 22). Dergide yazan Nurettin Artam (1943) bu durumu Türkiye'de sınırsız bir "kulak hürriyeti" olduğu vurgusuyla açıklamaktadır.

Yukarıda bahsedildiği gibi, radyonun bir propaganda aracına dönüştürülmesi ulus devletlerin kısa dalga bandı kullanarak uluslararası yayın yapan radyo istasyonları kurmayı önemsemelerini beraberinde getirmiş ve bu nedenle sayısız radyo istasyonu yayın yapmaya başlamıştır. Bu gelişme aslında dünyada da çok sınırlı bir faaliyet alanıyla ve büyük ölçüde dinleme faaliyetleriyle sınırlandırılmış olan radyo amatörlerini daha sınırlı bir alana hapsederek işlerini zorlaştırırken, radyo amatörlüğünün giderek radyo dinleme ve bu büyük radyolarla bağlantı kurma çabasına dönüşmesine yol açmıştır. Ulus devletlerin daha güçlü vericilerle kısa dalga bandını işgal ettiği bu ortamda radyo frekanslarının sınırları aşmasını ve radyo amatörlerinin bu radyoları dinlemesini engellemek de -ki bu radyolar yalnızca amatörlerce değil daha geniş kesimlerce de dinlenmektedir- mümkün değildir. Bu bağlamda Türkiye'de ısrarla yabancı radyoları dinleme özgürlüğünün olduğunun vurgulanması daha anlaşılır olmaktadır. Buna karşılık bir verici kurarak haberleşme yapılmasının ülke açısından güvenlik sorunlarına yol açacağı anlayışı sürdürülmeye devam etmiştir. 


\section{İkinci Dünya Savaşı Sonrası Dönemde Türkiye'de Yoğunlaşan Radyo İlgisi ve Amatör Radyoculuğun Ortaya Çıkışı}

İkinci Dünya Savaşı sonrası Türkiye'de radyo yayıncılığı alanında değişim taleplerinin dillendirilmeye, teknik gelişme konusunda yeni adımların atılmaya başlandığı bir dönem olmuştur. Dolayısıyla bu, amatör radyoculuk konusundaki hâkim yaklaşımın da değişmesi yönündeki taleplerin ortaya çıktığı bir dönemdir. O güne kadar yalnızca alıcı yaparak yayınları dinleme faaliyeti ile sınırlandırılan amatörler verici kurma ve yayın yapma isteklerini dile getirmeye başlamışlardır. $\mathrm{Bu}$ talepler Başbakanlık Basın Yayın Umum Müdürlügünce yayımlanan dergisinde de yansımasını bulmuştur (bkz. Ertuğ, 1945a, s. 3). Dünya elektronik endüstrisinde yaşanan gelişmelere paralel olarak radyonun yüzünü Batıya dönen ve kapitalistleşme sürecini hızlandıran Türkiye'de de giderek daha erişilebilir bir araç haline gelmeye başlaması bu ilginin ve taleplerin canlanmasında önemli bir unsur olmuştur (Ertuğ, 1945a, s. 3). Savaş yıllarında orduların telsiz haberleşmesi alanında intiyaç duydukları teknik personeli amatör radyocularla karşılaması ise Türkiye'de radyo işletmesinden sorumlu kesimlerin amatör radyoculuğu "milli savunmada oynayacağı rol" bağlamında desteklemelerine imkân vermiştir (bkz. Ertuğ, 1945b, s. 11).

Savaş sonrası dönemde özellikle basın üzerinde uygulanan baskılar gevşetilmiş, Demokrat Parti'nin (DP) muhalefeti ve basına desteği ile CHP iktidarının ödün vermek zorunda kalışı bu gelişmeleri hızlandırmıştır. Her ne kadar bu dönem CHP ve DP'nin ortak tutumu tek parti döneminin toplumsal canlanmayı kontrol altında tutma eğiliminde olan hâkim yönetim anlayışını sürdürmek yönünde olmuşsa da (Ahmad, 1983, s. 1995), çok partili parlamenter rejime geçiş halk kitlelerinin de dikkate alınmasını sağlayan bir süreci başlatmıştır (Boratav, 2005, s. 93; Keyder, 2007, s. 147). Bu ortamda radyo konusundaki katı tutum da gevşetilmeye, dinleyicilerin önemsendiği izlenimi yaratacak adımların atılması yönünde çabalar gösterilmeye başlanmıştır (Ahıska, 2005, s. 144; Ertuğ, 1949). Bu gelişmeler amatör radyoculuk talep ve faaliyetleri için de uygun bir ortam yaratmıştır.

Bu ortamda 3222 sayılı kanunun lise, sanat okulları ve üniversitelere eğitim amaçlı ve deneme mahiyetinde yapacakları yayın konusunda tanımış olduğu izinden yararlanma imkânı doğmuştur. Savaş sonrasında birçok lise ve üniversite radyo istasyonunun kurulmaya başlanması bunun açık bir göstergesi olmuştur (Aziz, 1971; illaslan, 2014a). Dolayısıyla bu, Türkiye'nin İkinci Dünya Savaşı sonrası girdiği yeniden yapılanma sürecinin beraberinde getirdiği gelişmelerin bir ürünü olmuştur. DP'nin iktidara geldiği 1950'lerin ilk yıllarında itibaren ise, artan refaha eklenen demokratikleşme umutları (Boratav, 2005, s. 102) devlet tekeli dışında kurulan radyolar için oluşan uygun ortamın sürmesini sağlamıştır. Dolayısıyla bu 
dönemde de devlet radyoları dışında kurulan radyoların sayısı artmaya devam etmiştir. 4

Radyo yayıncılığı alanındaki devlet tekeli karşısına dikilen bu çabalar amatör radyoculuk girişimlerini de cesaretlendirmiş, bu konudaki ilk girişimler yine bu dönemde, 3222 sayılı yasanın eğitim kurumları için açık bıraktığı kapıdan yararlanarak gerçekleştirilmiştir. İstanbul'da kurulan Telsiz Okulu bunun ilk örneği olmuştur. İsminde radyo amatörlüğünü taşıyan Radyo Amatörleri Derneği de bu okulun mezunları tarafından kurulmuştur. Türkiye'de kamu kurumlarının ihtiyaç duyduğu telsizcileri ve amatör faaliyetleri yürüten ve yaygınlaştıran isimleri yetiştiren de bu okul olmuştur. Böylece 1950'ler çağın eğlencesi olarak tanıtılan amatör radyoculuğun Türkiye'de daha sık gündeme gelmeye başladığı bir dönem olmuştur (Milliyet, 10 Kasım 1951, s. 3).

\section{Türkiye'de İlk Amatör Radyoculuk Derneğinin Kuruluşu}

1945-50 arası dönemde yaşanan gelişmelerin hazırladığı uygun ortamda bir yandan devlet radyocuları dışındaki ilk radyo istasyonları kurulurken, diğer yandan da halk arasında radyoya yönelik ilgi giderek yaygınlaşmıştır. Bu, radyoculuğun daha geniş kesimlerce ilgi duyulan bir faaliyet alanı haline gelmesi yönünde ilk adımların atıldığı ve amatör radyoculuk faaliyetlerinin hayata geçerek gündemdeki yerini aldığı bir dönemdir. Bu faaliyetlerin merkezi İstanbul olmuştur. Bunda devlet radyosu dışında ilk radyo istasyonunu kurarak faaliyete geçiren İstanbul Teknik Üniversitesi'nin rolü büyüktür. 1946 yılında Teknik Üniversite Radyosu'nu faaliyete geçiren İstanbul Teknik Üniversitesi'nden Doçent Mustafa Santur, aynı yıl Teknik Okul Radyosu'nun kuruluşuna da temel desteği veren isimdir. 60 watt'lık bir verici gücüyle faaliyet gösteren bu istasyon 1946 yılında Santur'un desteğiyle dördüncü sınıf öğrencileri tarafından faaliyete geçirilmiş ve 1950 yılından itibaren düzenli bir biçimde yayın yapmaya başlamıştır (Deniz, 11 Aralık 1952). Teknik Okula giderek görüşmeler yapan Ümit Deniz (11 Aralık 1952) 'teki köşesinde bu okulu konu edinmekte, okulun bine yakın öğrencisi olduğu, kısa dalga üzerinden akşam 19-20 saatleri arasında Pazar sabahları da 9:30-11:00 saatleri arası 44-45 metre üzerinden "Teknik Okul" anonsuyla yayınlar yaptığı bilgilerini vermektedir. Deniz'e bilgi veren radyo yetkilileri Adana ve Erzincan gibi illerden bile dinlenebildiklerini, bunu yayınlarını dinleyen izleyicilerden gelen destek mektuplarından anladıklarını belirtmişlerdir (Deniz, 11 Aralık 1952). Bu açıklama konumuz açısından önemli bir bilgi daha barındırmaktadır. Buna göre, dinleme şeklinde gerçekleştirilen amatör radyoculuk faaliyetlerinin ülkenin hemen her yerinde kendisine yer bulduğu görülmektedir. Çok küçük vericilerle yayın yapan kısa dalga radyo istasyonlarını dinlemenin özel çaba gerektiren bir uğraş olduğu göz önüne alınırsa, İstanbul'da faaliyet gösteren Teknik Okul

4 DP iktidarı döneminde kurulmaya başlanan devlet radyoları dışındaki radyo istasyonlarının sayısı 1960'lar ve 1970'lerde artmaya devam etmiştir. Bu istasyonların sayısındaki artışa bakıldığında bile radyoya ne kadar yoğun bir ilgi duyulmaya başlandığı rahatıkla görülmektedir. Bu radyolara dair bilgiler için bkz. Aziz, 1971; ilaslan, 2014a. 
Radyosunun Erzincan'dan dinlenmesi ancak amatör bir radyocunun uğraşları sonucu gerçekleşebilir. Hele ki bu dönemde devlet radyolarının bile ülkenin her yerinden rahatça dinlenemediği düşünülürse, Teknik Okul radyosunu uzak mesafelerden dinleyen ve ona yayınlarının o bölgelere kadar ulaştığını teyit edici nitelikte mektuplar gönderenlerin ciddi bir dinleme faaliyeti gerçekleştiren amatörler olduğu söylenebilir. Dolayısıyla bu dönem yoğunlaşan amatör radyoculuk faaliyetlerinin eğitim kurumlarının kurduğu radyolar bağlamında kendisine temel bir dayanak bulduğu görülmektedir. İstanbul Teknik Üniversitesi Radyosu, Teknik Okul Radyosu, Ankara Yüksek Eğitim Enstitüsü Radyosu gibi bu yıllarda faaliyet göstermeye başlamış olan örneklerin henüz yasal dayanağı olmayan amatör çabalara ciddi bir temel sağladığı söylenebilir.

Süreyya Erkilet tarafından 1949 yılında, yine İstanbul Teknik Üniversitesi'nden hocaların da desteğiyle, İstanbul'da aynı yıl kurulan ve Telsiz Okulu'yla bağlantılı olarak faaliyete geçirilen Radyo Amatörleri Derneği bu durumun açık bir göstergesi olmuştur. Telsiz Okulu 1950, 1951 ve 1952 yıllarında yüze yakın telsiz operatörü mezun etmiştir. Bu sayıya okuldan mezun olmadan ayrılanlar da eklenince telsiz kurarak işletebilecek eğitimli insanların sayısının bu dönemle birlikte giderek arttığı görülmektedir (Deniz, 11 Aralık 1952; Erkilet, 4 Ocak 1953, 2). Bu gelişme amatör radyoculuğun giderek daha profesyonel ve yaygın bir uğraşa dönüştüğünü göstermenin yanı sıra, serbest bırakılması taleplerinin de daha güçlü ve yeni temel dayanaklarla ifade edildiği bir dönemi başlatmıştır. Bu bağlamda amatör radyoculuğun ülkenin ihtiyaç duyduğu teknik personelin yetiştirilmesi, milli güvenliğin sağlanması ve ülkenin gelişmesine katkı yapması açısından kritik bir önem taşıdığı dile getirilmeye başlanmıştır (bkz. Erkilet, 4 Ocak 1953, 2; Erkilet, 7 Ocak 1953, 2). Örneğin 'teki köşesinde H.E. Erkilet Ulaştırma Bakanlığı, PTT, İçişleri Bakanlığı gibi devlet kurumlarının hepsinin teknik personele intiyaç duyduğunu bu nedenle de Telsiz Okulu'na ve amatör radyoculuk faaliyetlerine destek vermeleri gerektiğini dile getirmektedir (4 Ocak 1953, 2). Okul idarecilerinin başvurusuyla Deniz Kuvvetleri Komutanlığı'nın, okul öğrencilerine her hafta Heybeliada'daki deniz kursları komutanlığının idaresindeki elektronik laboratuarından yararlanma izni vermesi (Erkilet, 4 Ocak 1953,2) ise bu taleplerin -yasal düzlemde olmasa da- karşılık bulmaya başladığını göstermesi açısından dikkate değerdir. Ancak Erkilet, Türkiye'nin bir an önce yasal zeminde amatör radyoculuğun önünü açması ve teşvik edici bir tutum benimsemesi gerektiğini savunmakta ve General McBridge'nin Vatan gazetesinin başyazarı ile yaptığı görüşmede Türkiye'nin amatör radyoculuğu serbest bırakması gerektiği yönündeki yorumuna vurgu yapmaktadır (7 Ocak 1953, 2).

General McBride'le Haziran 1950'de gerçekleştirilmiş olan bu görüşme ilerleyen yıllarda da amatör radyoculuk tartışmalarının temel vurgularından biri olmaya devam etmiştir. DP iktidarı döneminde Amerika'yla kurulan ilişkilerin ve benimsenen serbest pazar anlayışının daha ileri boyutlara taşınması radyo alanında 3222 sayılı Telsiz Kanunun 5. maddesinin 1955, 1957 ve 1958'de tadil edilmesiyle karşılığını bulmuştur. Bu değişiklikler bağlamında devlet tekeli 
dışında resmi kuruluşlara ve şahıslara, resmi müesseselere, petrol arama şirketlerine ve ülke temsilciliklerine verici kurma izni vermenin önü yasal olarak açılmıştır (Gönenç, 1977, s. 252, 254-255; Kocabaşoğlu, 2010, s. 416-427; Resmi Gazete 3.7.1958). Ayrıca ABD ile 1954'te imzalanan ikili anlaşmalar gereği ABD üslerinde radyo kurulmasına da izin verilmiştir (Aziz, 1971, s. 118-122). Tüm bu düzenlemelere rağmen amatör radyoculuk için herhangi bir adım atılmaması dikkat çekicidir. Bu noktada DP iktidarının benimsediği ekonomi politikalarını ve Batı'yla kurduğu ilişkileri sürdürmeye yardım edecek düzenlemeleri gerçekleştirme eğiliminde olduğu, radyo konusundaki düzenlemelerde bunun açıkça görülebildiği söylenebilir. Buna karşılık ülke içinde radyoların gelişimine yönelik adımlar atmadığı görülmektedir (bkz. TRT, 1972, s. 6). Bir yandan benimsediği kontrolcü anlayış bağlamında devlet radyolarını yoğun bir biçimde kullanırken, tehdit olarak görmediği küçük girişimlere müdahale etme gereği de duymamış, radyo amatörlerinin önünü yasal olarak açacak bir adım atmaktan da kaçınmıştır. Dolayısıyla radyonun kullanımının iktidarın kontrolünden tamamen çıkması endişelerinin ve hala sürdürülmeye devam eden eski güvenlik kaygılarının bu yönde bir adımı engellediği söylenebilir.

Radyo amatörlüğü için uygun zeminin bir türlü oluşmadığı bu ortamda gizli olarak radyo amatörlüğü faaliyetini sürdüren kesimler olsa da, Telsiz Okulu'yla bağlantılı olarak kurulmuş olan Türkiye Radyo Amatörleri Derneği gerekli ivmeyi yakalayamamıştır. Ümit Deniz, 1952'deki yazısında İstanbul Beşiktaş'ta bulunan Telsiz Okulu ve Radyo Amatörleri Derneğini konu edinmekte, "ana tüzüğünde, memlekete radyo teknisyeni yetiştirmek gayesi ile kurulduğu yazılı olan" Türkiye Radyo Amatörleri Derneği'nin atıl bir durumda olduğunu belirtmekte ve derneğin genel sekreteriyle yaptığı görüşmeyi aktarmaktadır:

Dernek Genel Sekreteri bize şöyle dert yandı: "Dünyanın her tarafında radyo amatörü pek çoktur... Hâlbuki hür dünya devletleri arasında sadece bizde buna müsaade verilmemiştir. 1950 senesinde Ulaştırma Bakanlığına müracaat ederek amatör radyocuların lisansiye edilmesini, karşılıklı amatör neşriyat yapılmasını istedik. Cevap verdiler ve dediler ki: Dinleme ve kestirme istasyonları inşa ediliyor. Bunlar bittikten sonra telsiz kanununda tadilat yapılacaktır. O zaman sizin teklifiniz de hatırı itibara alınacaktır. Hâlbuki aradan seneler geçti hala bizim teklif hatırı itibara alınmadı (25 Aralık 1952, 2).

Bununla birlikte, daha önce de belirtildiği gibi, 1953 gibi erken bir tarihte yasal dayanağı olmamasına rağmen vericiler kurup radyo amatörlüğü yapanların varlığı dikkat çekici bir biçimde karşımıza çıkmaktadır. gazetesi, yayınları bozdukları ve çirkin neşriyat yaptıkları gerekçesiyle bu radyolardan şikâyet etmektedir:

Kısa dalga radyo istasyonlarını dinleyen radyo meraklıları gündüz, Ankara, İstanbul, İzmir ve hususi radyo istasyonlarının emisyonları dışında bazı yerleri belli olmayan amatör vericiler fevkalade çirkin mahiyette neşriyat yapmaktadırlar (...) Amatör radyocular kanununun henüz kabul edilmediği bu zamanda böyle neşriyat, dinleyenler için de cidden çirkin bir manzara arz etmektedir. Hassaten 51 ve 49 metre kısa bandı üzerinden muhtelif noktalarda tesadüf edilen bu tarz 
neşriyatın askeri bazı birlik telsizcileri ile amatör radyo heveskârı bazı kimseler tarafından yapıldığı zannedilmektedir. Gazetemiz radyo servisi tarafından da muhtelif zamanlarda dinlenen ve tespit edilen bu tarz neşriyat hakkında alakadarları ikazı bir borç biliyoruz (Milliyet, 4 Nisan 1953, s. 2).

Bu tür radyoculuk faaliyetlerinin yalnızca yayınları bozdukları ve çirkin neşriyat yaptıkları için değil, ülke güvenliğine karşı ciddi bir tehdit oluşturdukları gerekçesiyle de gündeme geldiği görülmektedir. İkinci Dünya Savaşı sonrası, özellikle 1950'ler ve 1960'lar, Türkiye'de radyo yayıncılığının içinde bulunduğu zor koşulların ve gelişmemişliğinin yabancı radyolardan duyulan kaygılar bağlamında tartışılığı bir dönem olarak karşımıza çıkmaktadır. Bu tartışmalarda Arap radyolarının, Suriye, Irak gibi ülkelerden yapılan yayınların toplumsal yapıda yaratacağı olumsuzluklar üzerinde durulmakta, bir an önce güçlü bir radyo şebekesi kurularak bu tür yayınların etkisinin en aza indirilmesi gerektiği hemen her radyo tartışmasında dile getirilmektedir (IIlaslan, 2014a, s. 125, 129). Bu bağlamda giderek pekişen radyonun toplum üzerinde güçlü bir etkide bulunduğuna ve bu nedenle devlet kontrolü dışındaki yayıncıı̆ğın ülke güvenliği için ciddi bir tehdit oluşturacağına dair hâkim kavrayış yurt içinde serbestçe faaliyet gösterme talebinde bulunan amatör radyocuların önündeki en temel engel olmuştur.

\section{0’lar ve Amatör Radyoculuk: Türkiye Radyo Amatörleri Cemiyeti}

1945 sonrası dönem ve 1950'lerin ilk yıllarında Türkiye'de amatör radyoculuğun serbest bırakılacağına dair yükselen umutlar kısa sürede yerini hayal kırıklığına bırakmıştır. Bu talep ve umutların yükselişinde aynı dönemde yaşanan toplumsal canlanma ve demokratik yöneliş umudunun temel bir rol oynadığı görülmektedir. Ancak 1950'lerin ikinci yarısıyla birlikte giderek içine sürüklenilen kriz ortamı ülkede radyo konusunda atıması beklenen adımların önünde de ciddi bir engel oluşturmuştur.

1950'lerde yaşanan ve bir türlü çözüme kavuşturulamayan siyasi, toplumsal ve ekonomik krizin ardından gelen 27 Mayıs darbesi genel olarak egemen sınıflar arasındaki çelişkinin ve çatışmanın sanayi burjuvazisi lehine çözüme kavuşturulduğu ve ülkenin bu bağlamda bir yeniden yapılanma sürecine sokulduğu bir adım olarak değerlendirilmektedir (Ahmad, 1996, s. 185; Boratav, 2010, s. 336; Keyder, 2007, s. 177, 180). Bununla birlikte 1961 Anayasasının toplumun büyük bir kesimine örgütlenme, siyasete katılma, hak talep etme ve muhalefet etme imkânı tanıyan bir nitelikte yapıldığı ve bu adımın yoğun bir toplumsal canlanmayı ve hemen her konuyu kamuoyu önünde rahatça tartışma imkânını beraberinde getirdiği görülmektedir (Ahmad, 1983, s. 1996; Keyder, 2007, s. 184).

$\mathrm{Bu}$ gelişmeler konumuz açısından önem taşımaktadır. 1960'larda yaşanan bu toplumsal canlanma ve özgür ortam radyo amatörlügüne olan ilginin yoğunlaşmasını ve bu konudaki taleplerin yeniden ve daha belirgin bir 
biçimde dile getirilmesini sağlamıştır. 51962 yılında Dr. Bedii Ezgi ve asistandan, öğretmene, telsiz operatöründen radyo tamircisine kadar yirmiyi aşkın kurucu üye tarafından İstanbul'da kurulan Türkiye Radyo Amatörleri Cemiyeti (TRAC) bu gelişmelerin bir yansıması olmuştur. Böylece henüz yasal dayanağı olmayan bir faaliyetin gerçekleştirilmesine ve yaygınlaştırılmasına talip ikinci bir örgütlenme girişiminde bulunulmuştur. TRAC günümüze kadar varlığını sürdüren uzun soluklu bir örgütlenme olmuştur. Bu sürecin yarıya yakın kısmı yine yasal dayanaktan yoksun bir biçimde, yalnızca üyelerin "gizli" ve eskiye nazaran daha yoğun bir biçimde gerçekleştirdikleri amatör radyoculuk faaliyetleriyle geçirilmiştir. Bu bağlamda TRAC Türkiye'de amatör radyoculuğun kurumsal tarihini bünyesinde barındırmaktadır. 1960 sonrası süreçte Türkiye' de yaşanan tüm olumsuz koşullara rağmen TRAC'ın bu kadar uzun süre varlığını koruması amatör radyoculuğun Türkiye iletişim tarihinde ihmal edilmemesi gereken bir araştırma alanı olarak karşımızda durduğunu göstermesi açısından da büyük önem taşımaktadır.

Ancak bu noktada 1961 Anayasasını hazırlayanların amatör radyoculuğu serbest bırakma gibi bir niyetlerinin olmadığını ve telsiz haberleşmesi ve radyoculuğun devletin tekeli ve sıkı kontrolü altında sürdürülmesinin ülke güvenliği açısından olmazsa olmaz olduğu yönündeki düşünceyi sürdürmeye devam ettiklerini belirtmek gerekir. Bunu anayasa tasarısı görüşmeleri sırasında "haberleşme hürriyeti"ni düzenleyen 17. madde etrafındaki tartışmalarda görmek mümkündür. Düzenlemenin ilk hali herkesin her türlü araçla haberleşme hürriyetine sahip olduğuna vurgu yapmaktadır. Bu vurgunun telsiz haberleşmesinin de önünü açacağı endişesi tartışmaları beraberinde getirmiştir. Muammer Aksoy bunun söz konusu olmadığını, telsizle haberleşme hürriyetinin "Vatandaşın sadece muhabere hürriyetine sahibolması gayesini" aştığını, "başka maksatlarla da kullanılabilecek vasıtalar üzerinde, Devletin kontrol hakkını tanıma"nın haberleşme hürriyetine ters bir düzenleme olmadığını belirtmiştir (Temsilciler Meclisi (TM) Tutanak Dergisi, 11.04.1961, B: 42, O: 2, s. 76). Bu ifadelerden de anlaşılacağı üzere, telsiz haberleşmesi tehlikeli görülen ve kesinlikle devletin denetimi altında tutulması gereken bir alan olarak görülmeye devam etmiştir. Bu madde üzerine çıkan tartışmada maddenin yeterince açık olmadığı ve eğer madde böyle kabul edilirse telsizle haberleşmenin de serbestçe yapılmaya başlanacağı ileri sürülmüş ve bunun önlenebilmesi için maddenin açıklığa kavuşturulması istenmiştir. Cemil Sait Barlas, madde açıklığa kavuşturulmazsa telsizle haberleşmenin önüne geçilmesinin mümkün olamayacağını ifade etmiştir. Kaludi Laskaris ise aynı birleşimde bu durumun sakıncalarını şöyle dile getirmiştir:

Arkadaşlar, bendeniz de benden evvel konuşan arkadaşımıza iştirak ediyorum. Her evde radyo vardır, bu alıcı ve verici olabilir, bir motor ilâvesiyle. Bu kelimeler

5 Örneğin 1962 yılında Elektrik Mühendisleri Odasının Amatör Radyoculuk Komisyonu amatör radyoculuğun serbest bırakılmasını talep eden bir bildiri hazırlamıştır. nin Nisan 1962 tarihli 64. sayısında "Türkiye'de Radyo Amatörleri Çalışmalarına Müsaade Edilmesi Hakkında Bildiri" başıĬıyla yayınlanan bu bildirinin tüm resmi makamlara gönderildiği de belirtilmektedir. 
pek şümullüdür. Millî Emniyet işe vaziyed edinceye kadar iş işten geçer. Bunu kim kontrol edecektir. Yakalanıncaya kadar memleketin sırları ortadan kalkar istenilen yere kadar gider. Onun için maddenin vuzuh bulması lâzımdır (TM, 11.04.1961, B: 42, O: 2, s. 76).

Bu tartışmalar neticesinde maddeden şahısların yapacağı telsiz haberleşmesine dayanak oluşturabileceği düşünülen "her türlü araçlarla" ibaresi çıkarılmıştır.

Bununla birlikte, 1960'larda gerek dünyada ve gerekse Türkiye'de radyo endüstrisinde yaşanan gelişmeler bağlamında radyonun toplumsal hayatta hızla yaygınlaşan ve daha kolay erişilebilen bir araca dönüşmesi Türkiye'de amatör radyocuların önündeki teknik engellerin daha rahat aşılmasını sağlamaya başlamıştır. Türkiye'de radyoların daha fazla önemsenmeye başlanması ve kalkınma planlarında radyoların geliştirilmesi ve yaygınlaştırılması için yatırım planlarına yer verilmesi radyonun topluma yaygınlaşmasının temel unsurlarından olmuştur. ${ }^{6}$ Bu yaygınlaşma radyo amatörlüğüne duyulan ilginin canlanmasında da önemli bir rol oynamıştır. Bu canlanmanın izi TRAC'ın gelişimi ve yaygınlaşmasında rahatlıkla sürülebilmektedir.

1960'ların başında her ne kadar amatör radyoculuğa izin verilmese de bu alanda teknik personele duyulan ihtiyacın eğitim kurumlarına verilen telsiz kurma ve işletme izniyle giderilmeye çalışıldığı görülmektedir. 3222 sayılı kanun lise, sanat okulları ve üniversitelere eğitim amaçlı ve deneme mahiyetinde yapacakları yayın konusunda bir serbestiyet tanımıştı. Bu kapsamda Türkiye'de birçok lise ve üniversite radyo istasyonu kurmuş ve kısa dalga üzerinden yayın yapmaya başlamıştı. Bu dayanakla, Milli Eğitim Bakanlığı 15.01.1962, cilt 25, 1188 sayılı Tebliğler Dergisi'nde valiliklere gönderdiği 5807 sayılı yazıyla kendisine bağlı eğitim kurumlarının radyo alıcı ve verici tesisleri kurabileceğini teyit etmiştir. Bu yazıda, ülkenin ihtiyaç duyduğu radyo teknisyenlerini yetiştirmek için 3222 sayılı kanunun 2. maddesine dayanarak orta ve yüksek dereceli okullarla üniversitelerde kurulacak alıcı ve verici tecrübe postaları ile yayın yapılabileceğine vurgu yapılması bu açıdan dikkate değerdir. Bu vurgu ülkenin teknik personele olan ihtiyacını ortaya koymaktadır, amatör radyoculuğun temel savunma dayanaklarından birini de ihtiyaç duyulan teknik personeli yetiştirme savı oluşturmaktadır. Ancak bu ihtiyaç bağlamında devletin, amatör radyoculuğu kontrol edememe ve bunun ülke güvenliğine tehdit oluşturacağı kaygılarıyla farklı bir çözüm yoluna başvurduğu görülmektedir. Çünkü Milli Eğitim Bakanlığına bağlı eğitim kurumlarının gerçekleştireceği amatör radyoculuk/telsizcilik faaliyetlerinin rahatlıkla sıkı bir kontrol altında tutulabileceği düşünülmektedir. Aynı düzenlemede bu kontrolü sağlayacak hükümlere yer verilmesi bunun açık bir göstergesidir. ${ }^{7}$

6 Bu dönemde radyo için yapılan yatıım planları ve radyonun Türkiye'deki teknik gelişimine dair ayrıntılı bilgi için Birinci ve İkinci ve Üçüncü Beş Yıllık Kalkınma Planlarına bakılabilir.

7 Bu konuda Ulaştırma Bakanlığı ile birlikte "Öğretim Maksadıyla Kurulmuş Olan ve Öğretim Maksadıyla Kullanılan Telsiz Verici ve Alıcılarına Dair Esaslar" başlığı altında belirlenen yayın 
Dolayısıyla bu dönemde amatör radyoculuk faaliyetlerinin yasal olarak resmi kurumlarla sınırlandırıldığı söylenebilir. Bunu TRT Kanun Tasarısı üzerine hazırlanan komisyon raporunda da görmek mümkündür. Bu bağlamda raporda, yayın tekelinin TRT'ye verilmesine karşın, "yayın mefhumuna girmediği yani kütleye hitaben bahis konusu olmadığı amatör radyoculuk ile -polis radyosu gibibelli bir hizmetin icabı olarak ve sırf o hizmetin sınırları içinde kalması gereken radyo tesislerinin" bu tekelin dışında kaldığının vurgulandığı görülmektedir (Millet Meclisi (MM) Tutanak Dergisi, 24.9.1963, B: 141). O dönem devlet tekeli dışında yalnızca eğitim kurumlarının ve belli kamu kurumlarının radyoculuk ya da eğitim ve haberleşme amaçlı telsizcilik faaliyetine -her ne kadar yasal dayanağı olmadan ve izinsiz kurulan birçok radyo istasyonunun varlığı söz konusu olsa daizin verildiği göz önüne alındığında bu durum daha iyi anlaşımaktadır. Ayrıca bu istasyonların da radyo yayını yapma anlamında yasal bir dayanağı yoktur, çünkü yayın tekeli devlet radyolarındadır. Bu nedenle bu istasyonların faaliyetlerinin "yayın mefhumuna" girmediğine ve "belli bir hizmetin sınırları içinde" kaldığına vurgu yapma intiyacı duyulduğu görülmektedir.

TRAC kurulduğu andan itibaren Türkiye'de radyo amatörlüğünün serbest bırakılmasını savunan ve hemen her fırsatta dile getiren bir dernek olmanın yanı sıra, ülkenin çeşitli yerlerinde radyo amatörlügü yapan kişileri buluşturan bir platform olmuştur. Cemiyetin Temmuz 1964'te yayımlamaya başladığı bu taleplerin ve amatör radyoculuğa dair geniş bir bilgi birikimin paylaşıldığı yer olmuştur. TRAC bir verici yaparak diğer radyo meraklılarıyla haberleşmenin serbest bırakılmasını sağlamayı ve bu tür bir amatörlüğü ülkedeki radyo meraklılarına benimsetmeyi ön plana alan bir anlayışla kurulmuştur. Cemiyetin ana tüzügünde yer verilen amaçlar arasında, "Dünyanın hiçbir yerinde bulunmayan verici yapma yasağının kaldırılması için gerekli çalışmalarda bulunmak" ifadesine yer verilerek bu hedef açıkça ortaya konmuştur. Dergilerinin Temmuz 1964 tarihli ilk sayısında karşımıza çıkan önsözde de bu amacı görmek mümkündür:

Birçoklarımızın bildiği gibi radyo amatörlüğü yalnız galenli ve transistorlu yahut da daha ilerlemiş meraklıların 5, 6 lambalı süper radyo veya amplifikatör yapma merakından ibaret olmayıp, belki de yurdumuzda tanııımadığından bambaşka bir merak ve zevki içine almaktadır. Bu ikinci bölüm radyo amatörünün bizzat imal veya bu iş için hazırlanmış takatı kanunen sınırlandırımış (takriben 50 watt civarında) bir alıcı ve verici radyo cihazı ile kendisi gibi meraklı diğer memleketlerde bulunan amatörlerle istediği kadar konuşmak zevkidir. Bu güne kadar memleketimizde 9.6.1937 tarih ve 3222 sayılı Telsiz Kanunu hükümleriyle

şartlarında, okullarda yapılacak tecrübe yayınlarında çalınacak müzik plaklarının yayından önce, yayınlanmasında mahzur olup olmadığının kontrolü için, marka ve numaralarının Umum Müdürlüğüne gönderilmesi istenmekte ayrıca bu istasyonlara söz yayını yapma izni verilmemektedir. Söz yayınları sadece radyo istasyonunun adını, yerini söylemekle ve yayın kalite ve şiddeti hakkında teknik konulara ait kısa soruların yöneltilebilmesiyle sınırlandırılmaktadır. Belirlenen şartların 'Isşletme' başlığı altındaki kısmında yer alan 15. maddesinde bu istasyonlara kayıt defteri tutma zorunluluğu da getirilmiştir. Bu deftere, "tesisin adı, çağırma harfleri, yayının tarihi, başladığı ve bittiği saat, kullanılan frekans ve hangi güçle çalıştığı, verici tesis portatif ise bulunduğu yer, neşriyatın mahiyeti başka bir tesis ile konuşulmuş ise kiminle ve ne konuşulduğu" kaydedilmesi istenmektedir. 
özel kişilerin radyo vericisi yapmak ve kullanmaları yasak edilmiş olduğundan bu zevk ve merak amatörlerin içinde kalmıştır.

Türkiye Radyo Amatörleri Cemiyeti ile Ankara Elektrik Mühendisleri Odası'nın memleketimizde de bu yasağın kaldırılması için yaptığı teşebbüsler müsbet netice vermiş ve Radyo Amatörlüğü Kanunu tasarısı hazırlanması hakkında Milli Güvenlik Kurulu tarafından Ulaştırma Bakanlığına yetki verilmiştir.

Bu alıntıdaki son vurguda radyonun teknik gelişimine ve elektronik sanayinin gelişimine katkı sağlayacağı düşünülen radyo amatörlüğüne daha olumlu yaklaşıldığına dair bir izlenim ortaya çıkmaktadır. Bu olumlu bakış bu dönemde Türkiye'de bir elektronik endüstrisinin kurulma çabalarının hız kazanması, bunun için Montaj Sanayi Talimatı 8 gibi çeşitli düzenlemelerin yapılması ve yerli radyo üretimini teşvik edecek tedbirlerin alınmasıyla yakından bağlantılıdır. Bu dönemde bir yandan radyo sanayi hızla gelişmeye, bir yandan devlet radyoları giderek ülkenin her yerini kapsar bir teknik kapasiteye kavuşturulmaya başlamış ve bu gelişmeler bağlamında radyo ilk kez teknik açıdan tüm topluma yaygınlaşan bir araç niteliğine kavuşmuştur. ${ }^{9}$ Ancak tüm bu olumlu ortam ve hava amatör radyocular için bir türlü yasal düzenlemeye dönüşmemiştir. Bununla birlikte TRAC faaliyetlerini giderek yaygınlaşan bir biçimde sürdürmeye devam etmiştir. Öyle ki TRAC 1965 yılında Uluslararası Amatör Telsizciler Birliğine (IARU) üye olmuştur (http://www.trac.org.tr/15-trac-hakkinda.html).

Tartışmalar sürerken 1966 yılında Ulaştırma Bakanı Seyfi Öztürk amatör radyoculuğu serbest bırakacak yeni bir Telsiz Kanunu tasarısının varlığını doğrulamıştır:

(...) Telsiz Kanunu Tasarısı, Ulaştırma Bakanlığı görevine başladığım günlerden itibaren birinci planda olduğu önem zamanında takdir edilmiş bulunan bu konuyla 8 Şubat 1966 tarihinde Başbakanlığa sunulmuş bulunmaktadır. Halen Millet Meclisinin ilgili komisyonlarınca incelenmekte olan bu tasarıda amatör telsizciliği teşvik edici hükümler yer almış bulunmaktadır. ${ }^{10}$

Bu tasarı bu tarihten sonra zaman zaman gündeme gelmeye devam etmiştir (bkz. sayı 3-4 Nisan 1967, s. 20; , 1968, sayı 39, s. 9). Ancak bir türlü hayata geçirilememiştir. 1960'ların sonları 1970'lerin başlarında ülkenin içine sürüklendiği kriz ortamı ise umutların bir süre daha ertelenmesine yol açmıştır.

8 Bu talimatname elektronik sanayini bir plan ve program çerçevesinde şekillendirmeye yönelik ilk adımlardan biridir. 04.04.1964 tarihli Bakanlar Kurulunda kararlaştırılan 6/2905 sayılı bu düzenleme 14.4.1964 tarih ve 11682 sayılı 'de yayınlanarak yürürlüğe girmiştir. Bu tarihten itibaren radyo üretimi hızla artmış, elektronik sanayinin temel ürünü haline gelmiştir (PTT, 1967, s. 10-11).

9 1970'lere gelindiğinde nüfusun yaklaşık \% 82'si mevcut vericilerin kaplama alanına girmiştir (DPT, 1971, s. 8).

10 Bakan bu açıklamayı Hürriyet gazetesinde 14.5.1966 ve 20.5.1966 tarihlerinde yayımlanan ve amatör radyoculuğu yasaklayan Telsiz Kanununu eleştiren yazılar üzerine yapmıştır. TRAC dergisi bu haberleri ve bakanın açıklamasını Temmuz-Ağustos 1966 tarihli 25-26. sayısında yeniden yayımlamışır. Buradaki alıntı da bu kaynaktan yapılmıştır. 
Bununla birlikte amatör radyoculuğa olan ilgi ve amatör radyoculuk faaliyetleri artarak devam etmiştir. TRAC'ın İstanbul dışındaki diğer başka illerde şubelerinin kurulmaya başlanması bunun en açık kanıtıdır. 8.10.1965'te Cemiyetin Ankara şubesi faaliyete geçerken, 29.11.1965'te Sivas şubesi ve Aralık 1965'te de Tarsus şubesinin kurulduğu görülmektedir (bkz. TRAC, 1966, sayı: 23-24, s. 43-46). Derginin 1966 tarihli 23-24. sayısında Türkiye'de radyo amatörlerinin sayısının hayli yüksek olduğuna değinilmekte ve amatörlerin birbirinden haberdar olması ve birbirini tanıması için "Amatörleri Tanıyalım" başlığı altında bir köşeye yer verilmektedir (bkz. s. 54). Bunun dışında da ilerleyen sayılarda TRAC üyesi amatörlere dair bilgiler verilmeye devam edilmiştir (bkz. TRAC, sayı 3-4, Nisan 1967, s. 19). Derginin Türkiye'de amatör radyocuların dinleme faaliyetlerine dair her hafta yayınladığı bilgilere bakıldığında bile radyo amatörlerinin Türkiye'nin birçok ilinde ve giderek artan bir sayıyla faaliyet göstermeye devam ettikleri rahatıkla görülmektedir.

Bu bağlamda tüm yasaklara rağmen bir verici kurarak gerçekleştirilen amatör radyocuk faaliyetlerinin de varlığı görülmektedir. Bahri Kaçan (1969) TRAC dergisinde yazdığı yazıda bunun uzun süredir gizli olarak yapılmaya devam ettiğini, yakalanan gizli radyoların bunun en açık göstergesi olduğunu belirtmektedir. Türkiye'de gizli radyoculuk faaliyeti gösterenlerin sayısının 1960'larda hızla arttığı görülmektedir. Bu konuyu daha 1964'te Milliyet'teki köşesine taşıyan Faruk Yener şunları söylemektedir:

\begin{abstract}
Ulaştırma Bakanı Sayın Alpiskender Manisa'da verdiği bir demeçte sınırlarımız içinde yayın yapan gizli radyo istasyonlarının arttığını söylemiş, Milli Savunma Bakanlığının isteği üzerine bunların serbest bırakılacağını belirtmiş. Türkiye'de "Amatör Radyoculuk" 1937 tarihli ve 3222 sayılı 'Telsiz Kanunu' ile yasaklanmış, aradan uzun bir süre geçmesine, yurt ve dünya şartlarının çok değişmesine rağmen bu yasaklamanın kaldırıması düşünülmemiştir. Halbuki demokrasi ve özgürlük ilkeleriyle pek bağdaşmayan bu kararın çoktan kaldırılması gerekirdi (21 Ekim 1964, s. 6).
\end{abstract}

Böylece 1970'lere gelindiğinde Türkiye'de amatör radyoculuk faaliyetlerinin, yasak olmasına rağmen, adından söz ettiren bir etkinliğe dönüştüğü görülmektedir. 19 Temmuz 1970'te Telsiz Kanunu'nun değişmesi talebiyle bir basın toplantısı düzenleyen TRAC II. Başkanı Eşref Adalı cemiyetin İstanbul'da 500, Anadolu'nun 13 ilindeki şubelerine bağlı 4 bine yakın üyesi olduğunu belirtmiştir (Milliyet, 20 Temmuz 1970, s. 11). Bu bilgiler radyo amatörlüğünün ne kadar yaygınlaştığını göstermesi açısından önemlidir. Abdi Ipekçi 30 Kasım 1970 tarihli 'teki köşesinde Eşref Adalı ile bir röportaj gerçekleştirmiştir. TRT tartışmalarının yoğunlaştığı, televizyon yayıncılığının başlatılığı ve yoğun bir gündem maddesine dönüştüğü bu dönemde İpekçi'nin köşesini amatör radyoculuğa ayırması bu konunun ne kadar gündemde olduğunu göstermesi açısından dikkate değerdir. Adalı, söyleşide cemiyete gelen kartlardan Türkiye'de amatör radyoculuğun aktif bir biçimde yapıldığının görüldüğünü, isimlere bakılırsa bunların çoğunun yabancı olduğunu ancak arada Türk isimlerine de rastlandığını belirtmektedir. Tabi bu 
Türkçe isimlerin gerçekten Türk radyo amatörü mü yoksa Türkçe isim kullanan yabancı amatörler mi olduğunu bilmedikleri vurgusunu da ihmal etmemektedir. Bununla birlikte Adalı'nın şu cümleleri Türkiye'de amatör radyoculuğun, tıpkı yasal dayanağı olmadan devlet radyoları dışında yayın yapan radyolar gibi, fiili olarak yapıldığını göstermektedir ${ }^{11}$ :

\begin{abstract}
Radyo amatörleri en azından ulusun propagandasını yapıyor, kartını gönderiyor. Mesela kartının üzerinde bir Rus "uzaya ilk defa biz çıktık" diyor. İsveçli "Volvo arabası bizimdir" diyor. Biz de Türk olarak İstanbul'un fethini dünyaya duyurmak için yarışma yaptık. Bütün uluslara duyurduk. Bugün istanbul'un fethidir, buyurun katılın dedik (...) Yarışmalar şöyle oluyor: O gün beş Türk amatörü ile konuşan İstanbul diploması alacak (...) 15-20 tane oldu. Epey de uzak yerden konuşanlar oldu.
\end{abstract}

İpekçi'nin konuyu ele almasının ardından Basın-Yayın ve Turizm Müdürü'ne bu konuda bir açıklama yazısı göndermiş ve yeni hazırlanan Telsiz Kanunundan bahsederek, bu tasarıda amatör radyoculuğa da yer verildiğini, yasa yürürlüğe girdikten sonra amatör radyocuların taleplerine cevap verilebileceğini belirtmiştir (Milliyet, 24 Ekim 1970, s. 5).

Bu yöndeki olumlu değerlendirmeler aynı dönemde elektronik sanayinin hızlı bir gelişim sürecine girmesi ve radyonun hızla yaygınlaşmaya devam etmesiyle yakından bağlantılıdır. Bu bağlamda 1970'lerin başında elektronik sanayinin en önemli üretim kolu olan radyo ve televizyon üretiminin önündeki bütün engellerin kaldırılmasının hedeflendiği de görülmektedir. 12 Mart sonrası süreçte yaşanan gelişmeler -özellikle televizyona yapılan büyük yatırımlarbunun açık bir göstergesidir (ilaslan, 2014b). Bu süreçte hayata geçirilen Üçüncü Beş Yıllık Kalkınma Planında elektronik sanayinin gelişimine özel bir önem verileceğine yapılan vurgu da bunun bir yansıması ve habercisi niteliğindedir. Bu bağlamda, Üçüncü Planda, 3222 sayılı Telsiz Kanununun amatör radyoculuğu yasaklamış olması da ele alınmış ve bunun yerli elektronik sektörünün gelişimini engelleyen faktörler arasında yer aldığına değinilmiştir. Dolayısıyla Telsiz Kanunu'nun değiştirilerek amatör radyoculuğun serbest bırakılacağı planın temel hedefleri arasındaki yerini almıştır (DPT, 1972, s. 173-175). Üçüncü Planda amatör radyoculuğa yapılan bu vurgu konunun endüstriyel bakımdan ne kadar önemsenmeye başlandığını göstermesi açısından önemlidir.

Bu süreçte TRT de tüm dünyayı saran amatör radyoculuk faaliyetlerine aktif bir ilgi göstermeye başlamıştır. Kısa dalga üzerinden uluslararası yayın yapan devlet radyoları kendilerini uzak mesafelerden dinleyen amatör radyocularla bağlantı kurarak yayınlarının nerelere ve ne kalitede ulaştığını tespit etmeye çalışmışlardır. Bu noktada, birbiriyle haberleşme dışında radyo yayınlarını takip etmeyi bir uğraş haline getiren amatör radyocular, bir başka deyişle DX'ciler

11 Bu dönem gazetelerde amatör radyocuların yakalandığına dair çıkan haberler de bunun açık bir göstergesidir (Milliyet, 10 Temmuz 1970, s. 11; Milliyet, 16 Haziran 1971, s. 9). 
ortaya çıkmıştır. Kısa dalga devlet radyoları DX'cilerle bağlantı kurmak için onlara "doğrulama kartları" göndermiştir. TRT'de bu tür taleplere karşılık vermeye başlamıştır. Bu kapsamda 1972 yılında 21 ülkeden 3600 yabancı DX'ci TRT Dış Yayınlar Servisinden "doğrulama kartı" istemiştir. Bu talepler karşısında TRT ilk kez o dönemde üç dilde on bin adet renkli doğrulama kartı (QSL) bastırmıştır (Sağdıç, 1973, s. 3). Ozan Sağdıç, bu konuda kaleme aldığı yazıya dair gelen mektup ve telefonlardan Türkiye'de de çok sayıda DX'cinin olduğunu anladığını belirtmektedir (1973, s. 3).

Tüm bu gelişmelere rağmen 1970'lerde de amatör radyoculuğu serbest bırakan düzenleme yasalaşmamıştır. Artan ilgi, fiili olarak sürdürülen faaliyetler ve bu konuda oluşan kamuoyuna rağmen bir türlü beklenen adım atılamamıştır. 1971 darbesi, ardından gelen koalisyon hükümetleri dönemi ve 1970'lerin sonlarına doğru giderek içine sürüklenilen siyasi, toplumsal ve ekonomik kriz ortamı bir kez daha amatör radyoculuğun önüne dikilen en büyük engel olmuştur. Öyle ki, TRAC'ın tarihçesinde, 1970'lerin sonlarına gelindiğinde TRAC'ın bile Anadolu'daki amatör radyoculuk faaliyetlerinin azaldığı ve yalnızca İstanbul'la sınırlı bir çekirdek kadro tarafından yürütülmeye çalışıldığına değinilmektedir (http://www.trac. org.tr/15-trac-hakkinda.html). Bunda bu dönem radyonun televizyon karşısında giderek geri plana düşmesinin de payı olduğu söylenebilir.

\section{Sonuç}

Amatör radyoculuk, frekansların kamu tarafından aktif kullanımı bağlamında radyo tarihinin önemli bir uğrağı olarak karşımıza çıkmaktadır. Bu niteliğiyle bir anlamda radyonun demokratik potansiyelini de açığa vurmaktadır. Buna karşın uzun tarihsel süreç amatör radyoculuğun teknik, siyasi, askeri ve ekonomik gerekçelerle alandan büyük ölçüde dışlanmasına, birçok ülkede ise daha en başından alana dâhil edilmemesine tanıklık etmiştir. Ancak bu durum gerek haberleşme açısından gerekse toplumsal açıdan önemli roller taşıyan bu etkinliği ortadan kaldırmamış, amatör radyocular hemen her dönem frekansları aktif bir biçimde kullanmaya devam etmişlerdir. Öyle ki yasal dayanağı olmayan ülkelerde bile ilgi duyulan ve hayata geçirilen bir faaliyet olmuştur.

Radyoyla 1920'li yıllarda tanışan ancak, 1980'li yıllara kadar amatör radyoculuğun yasak olduğu Türkiye'de radyo tarihi bu açıdan önemli veriler sunmaktadır. Bu uzun süreçte amatör radyoculuğun özellikle güvenlik kaygılarıyla yasaklandığı görülmektedir. Frekansların kamu tarafından serbest bir biçimde kullanımının ülke güvenliğine ciddi bir tehdit oluşturacağı kaygıları had safhadadır. Bu nedenle amatör radyoculuğa hemen hiçbir dönem olumlu yaklaşılmamıştır. Demokratikleşme umutlarının yükseldiği ve toplumsal canlanmaların yaşandığı dönemlerde bile bu kaygının belirgin bir biçimde sürdürüldüğünü söylemek mümkündür. 1945 sonrasında yaşanan gelişmeler bağlamında Türkiye'de amatör radyoculuk tartışma ve faaliyetlerinin izi sürüldüğünde bu durum net bir biçimde görülmektedir. Öyle ki bir taraftan radyonun teknik açıdan gelişerek 
tüm topluma yayıldığı diğer taraftan ise ülkede kurulacak elektronik endüstrisi açısından en önemli araç konumuna yükseldiği 1960 'lı ve 1970 'li yıllarda bile amatör radyoculuğu serbest bırakacak düzenlemeleri hayata geçirmek mümkün olmamıştır. Bunda Türkiye'de yaşanan siyasi ve ekonomik çalkantıların, iktidarların radyo yayıncılığına ve kamuya bakışlarının da temel bir rolü vardır.

Bununla birlikte, Türkiye'deki yayın tekeline ve amatör radyoculuğu yasaklayan düzenlemelere rağmen 1945 sonrası dönemde bu konuya ilgi duyan kesimler, ortaya çıkan uygun koşulların da etkisiyle, aktif bir biçimde faaliyet göstermeye başlamışlardır. Telsiz Okulu ve TRAD'la başlayan, 1960'larda TRAC'ın kurulmasıyla kalıcılık kazanan amatör radyoculuk tüm yasal ve teknik sınırlamalara rağmen hayata geçerken, 1983'te edindiği yasal dayanakla günümüzde de varlığını sürdürmektedir. Yalnızca teknik bir merakın ötesinde bir anlam taşıyan bu uğraş Türkiye iletişim tarihi açısından önemi inmal edilmemesi gereken bir araştırma alanı olarak karşımızda durmaktadır.

\section{Kaynakça}

Ahıska, M. (2005). Radyonun Sihirli Kapısı: Garbiyatçılık ve Politik Öznellik. İstanbul: Metis.

Ahmad, F. (1983). "Türkiye'nin Cumhuriyet Dönemi Siyasal Gelişmeleri". Cumhuriyet Dönemi Türkiye Ansiklopedisi, c. 7, ss. 1991-1998.

Ahmad, F. (1996). Demokrasi Sürecinde Türkiye. (A. Fethi, Çev.). İstanbul: Hil Yayın.

Artam, N. (1943). Kulak Hürriyeti. Radyo, c.2, s. 22.

Aziz, A. (1971). Yurdumuzda TRT Dışındaki Yayın Durumu. AÜ. Siyasal Bilgiler Fakültesi Dergisi, c. 26, sayı. 4, ss.113-137.

Bener, F. M. (1941). Radyomuz 15 Yaşında. Radyo, c.1, sayı 1, ss. 4-5.

Berg, J. S. (2008). Broadcasting on the Short Waves: 1945 to Today. Jefferson, North Carolina: McFarland\&Company.

Beşiroğlu, A. (1977). Türk Radyo Hizmetlerinin Illk Belgesi. TRT Yayıncııı ve Haberleşme Dergisi, s. 27, ss. 1-5.

Boratav, K. (2005). Türkiye İktisat Tarihi 1908-2002. Ankara: İmge.

Boratav, K, (2010). Emperyalizm, Sosyalizm ve Türkiye. Istanbul: Yordam Kitap.

Briggs, A. ve Burke, P. (2011). Medyanın Toplumsal Tarihi: Gutenberg'den Internet'e. (Ü. H. Yolsal ve E. Uzun, Çev.). İstanbul: Kırmızı Yayınları.

Curran, J. ve Seaton, J. (2003). Power Without Responsibility: The Press and Broadcasting in Britain. London, New York: Routledge.

Çirkin Neşriyat. (4 Nisan 1953). Milliyet. 2. 
Demirci, K. (2014). Türkiye'de 2000 Sonrası Genel Seçim Kampanyalarında Demokrasi Söylemi. Mülkiye, 38 (1), 35-73.

Demirci, K. (2015). Türkiye'de Yurttaş-Devlet Illetişimi Açısından E-Devlet Uygulamaları: BiMER Örnek Olayı. Akdeniz İletişim Dergisi, 23, 96-114.

Deniz, Ü. (11 Aralık 1952). Alo... Burası Teknik Okul deneme radyo istasyonu. Milliyet. 6.

Deniz, Ü. (25 Aralık 1952). Türkiye Radyo Amatörleri Derneği ve Telsiz Okulu. Milliyet. 2.

Douglas, S. J. (2010). Radyonun Illk Yılları. (B. Ersöz, Çev.). D. Crowley ve P. Heyer, (Ed.). İletişim Tarihi içinde. (312-321). Ankara: Phoenix.

DPT (1971). Üçüncü Beş Yılıı Kalkınma Planı Radyo ve Televizyon Özel İhtisas Komisyonu Raporu. Ankara.

DPT (1972). Üçüncü Beş Yıllık Kalkınma Planı. Ankara.

Erkilet, H. E. (4 Ocak 1953a). Milli Bir Dava: Teknik Personel İhtiyacımı. Milliyet. 2.

Erkilet, H. E. (7 Ocak 1953b). Bizde Radyo Amatörleri Teşvik Edilmelidir. Milliyet. 2.

Ertuğ, H. R. (1945a). Amatör Radyoculuk. Radyo, c.4, sayı. 39, ss. 3.

Ertuğ, H. R. (1945b). Amatör Radyoculuk II. Radyo, c.4, sayı 41, ss. 11.

Ertuğ, H. R. (1949). Dinleyicilerimizle Hasbihal. Radyo, c.8, sayı 85-86.

Ertuğ, H. R. (1951). Radyo İşletmeciliği ve Meseleleri. İstanbul: İstanbul Üniversitesi Yayınları.

Gönenç, G. (1977). Türkiye'de Radyo ve Televizyonun Tarihçesi. Elektrik Mühendisliği Dergisi, c.21, sayı. 246-247, 251-271.

Hilmes, M. (1997). Radio Voices: American Broadcasting, 1922-1952. The University of Minnesota Press.

İlaslan, S. (2014a). Türkiye'de Radyonun Unutulan Sesleri: 1945-1980 Arasında Devlet Radyoları Dışında Kurulmuş Radyolar. Akdeniz Üniversitesi İletişim Fakültesi Dergisi, 21, 118-142.

İlaslan, S. (2014b). Türkiye'nin Yeniden Yapılanma Sürecinde Televizyon: 12 Mart Sonrası Dönemde Televizyon Yayıncılığının Kontrolü ve Yaygınlaştırılması. KTÜ Illetişim Araştırmaları Dergisi, 8, 33-55.

Ipekçi, A. (30 Kasım 1970). Her Hafta Bir Sohbet: Amatör Radyoculuk. Milliyet, 9.

Jeanneney, J. N. (2009). Başlangıcından Günümüze Medya Tarihi. (E. Atuk, Çev.), İstanbul: YKY. 
Kaçan, B. (1969). Radyo Amatörlüğü. TRAC Mecmuası, c.4, sayı. 3, ss. 3.

Keyder, Ç. (2003). Türkiye Demokrasisinin Ekonomi Politiği. Der. Schick, I. C. ve Tonak, E. A. (Der.), Geçiş Sürecinde Türkiye içinde. (38-75). İstanbul: Belge Yayınları.

Keyder, Ç. (2007). Türkiye'de Devlet ve Sınıflar. İstanbul: İletişim Yayınları.

Kocabaşoğlu, U. (2010). Şirket Telsizinden Devlet Radyosuna: TRT Öncesi Dönemde Radyonun Tarihsel Gelişimi ve Türk Siyasal Hayatı İçindeki Yeri. İstanbul: Iletişim.

Mattelart, A. (2001). İletişimin Dünyasallaşması. (H. Yücel, Çev.). İstanbul, Iletişim.

McChesney, R. (1993). Telecommunications, Mass Media, and Democracy: The Battle for the Control of Broadcasting 1928-1935. New York: Oxford University Press.

PTT (1967). Türkiye'de Elektronik Sanayii Kuruluş Raporu. Ankara.

Radyo Amatörleri Telsiz Kanununun Değişmesini İstiyor. (20 Temmuz 1970). Milliyet. 11.

Radyo Amatörü Lise Öğrencisi Bir Yıla Mahkum Oldu. (10 Temmuz 1970). Milliyet. 1.

Sağdıç, O. (1973). DX Türkiye'de de ilgi görüyor. Milliyet TV Radyo, 12 Mart.

Sıkıyönetim Mahkemesi evlerinde telsiz olan 2 genç için görevsizlik kararı verdi. (16 Haziran 1971). Milliyet. 9.

Stevenson, J. (1996). The Silencing of a Democratic Medium: Early Public Policy on Radio and the Regulation of the Internet. http://www.isoc.org/inet96/ proceedings/e2/e2_3.htm

TRAC-Türkiye Radyo Amatörleri Cemiyeti: http://www.trac.org.tr/15-trachakkinda.html

TRT (1972). TRT 1972 Yılı Faaliyet ve Mali Bünye Raporu. Ankara.

Tunçay, M. (1983). Siyasal Gelişmenin Evreleri. Cumhuriyet Dönemi Türkiye Ansiklopedisi, c.7, 1967-1990.

Walker, J. (2001). Rebels on the Air: An Alternative History of Radio in America. New York: New York University Press.

Yener, F. (21 Ekim 1964). Bizden-Onlardan. Milliyet. 6.

Yirminci Asrın Son Teknik Eğlencesi Telsizcilik. (10 Kasım 1951). Milliyet. 3.

Zürcher, E. J. (2007). Modernleşen Türkiye'nin Tarihi. (Y. Saner Gönen, Çev.). İstanbul, Illetişim. 